\title{
Primary production in the Chukchi Sea with potential effects of freshwater content
}

\author{
M. S. Yun ${ }^{1}$, T. E. Whitledge ${ }^{2}$, D. Stockwell ${ }^{2}$, S. H. Son ${ }^{3}$, J. H. Lee ${ }^{1}$, J. W. Park ${ }^{1}$, D. B. Lee ${ }^{1}$, J. Park ${ }^{1}$, and S. H. Lee \\ ${ }^{1}$ Department of Oceanography, Pusan National University, 30, Jangjeon-dong, Geumjeong-gu, Busan 609-735, South Korea \\ ${ }^{2}$ Institute of Marine Science, University of Alaska Fairbanks, Fairbanks, AK 99775-7220, USA \\ ${ }^{3}$ CIRA, Colorado State University, Fort Collins, CO, USA
}

Correspondence to: S. H. Lee (sanglee@pusan.ac.kr)

Received: 27 April 2015 - Published in Biogeosciences Discuss.: 20 August 2015

Revised: 22 January 2016 - Accepted: 25 January 2016 - Published: 10 February 2016

\begin{abstract}
The in situ primary production rates and various environmental variables were investigated in the Chukchi Sea during the RUSALCA expedition, which was conducted in 2012, to identify the current status of primary production. A ${ }^{13} \mathrm{C}-{ }^{15} \mathrm{~N}$ dual-tracer technique was used to measure the daily primary production rates, which ranged from 0.02 to $1.61 \mathrm{~g} \mathrm{C} \mathrm{m}^{-2} \mathrm{~d}^{-1}$ (mean $\pm \mathrm{SD}=0.42 \pm 0.52 \mathrm{~g} \mathrm{C} \mathrm{m}^{-2} \mathrm{~d}^{-1}$ ). The primary production rates showed large regional differences, with the southern region $\left(0.66 \pm 0.62 \mathrm{~g} \mathrm{C} \mathrm{m}^{-2} \mathrm{~d}^{-1}\right)$ producing approximately 5 times as much as the northern region $\left(0.14 \pm 0.10 \mathrm{~g} \mathrm{C} \mathrm{m}^{-2} \mathrm{~d}^{-1}\right)$, which was primarily due to the differences in phytoplankton biomasses induced by regional nutrient conditions. The primary production rates in the Chukchi Sea were averaged using data acquired during the three different RUSALCA expeditions (2004, 2009, and 2012) as $0.33 \mathrm{~g} \mathrm{C} \mathrm{m}^{-2} \mathrm{~d}^{-1}\left(\mathrm{SD}=0.40 \mathrm{~g} \mathrm{C} \mathrm{m}^{-2} \mathrm{~d}^{-1}\right)$, which was significantly lower than previously reported rates. In addition to strong seasonal and interannual variations in primary production, recent decreases in the concentrations of major inorganic nutrients and chlorophyll $a$ could be among the reasons for the recent low primary production in the Chukchi Sea because the primary production is mainly affected by nutrient concentration and phytoplankton biomass. The nutrient inventory and primary production appear to be largely influenced by the freshwater content (FWC) variability in the region due to the significant relationships between FWC, nitrate inventory $(r=0.54, p<0.05)$, and primary production rates $(r=0.56, p<0.05)$. Moreover, we found highly significant relationships between the nutrient inventory and the primary production rates $(r=0.75$,
\end{abstract}

$p<0.001)$. In conclusion, the primary production in the Chukchi Sea is primarily controlled by nutrient availability, which is strongly related to the FWC variability. Our results imply that the predicted increase in freshwater accumulation might cause a decrease in primary production by lowering the nutrient inventory in the euphotic zone of the Chukchi Sea.

\section{Introduction}

Over recent years, the Arctic Ocean has undergone drastic changes in the extent and thickness of sea ice (Stroeve et al., 2008; Comiso et al., 2008; Kwok et al., 2009; Overland and Wang, 2013). The continuing loss of sea ice may result in changes to various physical and chemical environmental conditions in the Arctic Ocean. For example, the loss in sea ice cover allows more sunlight to enter the surface layer of the Arctic Ocean, which results in a longer growing season for phytoplankton growth (Arrigo et al., 2008; Ardyna et al., 2014). Stroeve et al. (2014) reported that the Arctic melt season has lengthened at a rate of 5 days per decade from 1979 to 2013, due to later fall freeze-up. In accordance with their findings, Ardyna et al. documented the development of a second bloom in the Arctic Ocean during the fall, which coincides with the delayed freeze-up and the increased exposure to wind stress.

However, the loss in sea ice can cause an increase in the input of freshwater (McPhee et al., 2009). In fact, the freshwater volumes in the Canada and Makarov basins increased by $8500 \mathrm{~km}^{3}$ in 2008 due to increased sea ice melting and 
river discharge (McPhee et al., 2009; Rabe et al., 2011). This phenomenon can enhance the stratification in the upper ocean (Yamamoto-Kawai et al., 2009) and consequently reduce vertical mixing, thereby preventing nutrient inputs from deep waters to the euphotic zone. In fact, McLaughlin and Carmack (2010) found a deepening of the nutricline due to the accumulation of surface freshwater in the Canada Basin.

In the Chukchi Sea as inflow shelf, there was an increased volume flux of $50 \%$ in $2011(\sim 1.1 \mathrm{~Sv})$ relative to 2001 $(\sim 0.7 \mathrm{~Sv})$, which was accompanied by increases in heat and freshwater fluxes (Woodgate et al., 2012). Though the volume flux may vary both seasonally and annually under the influence of the local wind fields, the recent increases in freshwater fluxes in the region may have important implications for phytoplankton in terms of nutrient availability for their growth (Woodgate et al., 2005a, b, 2006). Thus, it is important to identify how phytoplankton respond to these environmental changes in the region in terms of production and/or community structure. According to Li et al. (2009), the phytoplankton community has changed under the freshening and stratifying condition in the Canada Basin. Notably, the abundance of small phytoplankton $(<2 \mu \mathrm{m})$ has increased, whereas the abundance of large phytoplankton (2$20 \mu \mathrm{m})$ has decreased. Yun et al. (2014) also found that, compared with previous reports, the small phytoplankton were more abundant on the Chukchi Sea shelf, which is dominated by low levels of nutrients and freshening conditions. Therefore, the changes in recent phytoplankton production under the rapidly changing environmental conditions need to be monitored because the changes in phytoplankton production could have important implications for understanding ecosystem changes in the Arctic Ocean.

In order to understand climate and ecosystem change in the Pacific-Arctic Ocean, a region where summer sea ice content has been remarkably declining (Crane and Ostrovskiy, 2015), the RUSALCA (Russian-American Long-term Census of the Arctic) expedition, which is a joint USRussian research program, started from 2004 as multidisciplinary investigations in the Bering and Chukchi seas. Three RUSALCA expeditions (2004, 2009, and 2012) provided a good opportunity for continuous measurements of the primary production in the entire Chukchi Sea, including the exclusive economic zone of the Russian Federation: the 2004 RUSALCA expedition was conducted from 8 to $24 \mathrm{Au}-$ gust 2004 (Lee et al., 2007), the 2009 RUSALCA expedition from 1 to 30 September 2009 (Yun et al., 2014), and the 2012 RUSALCA expedition from 27 August to 16 September 2012. This study is part of the 2012 RUSALCA expedition.

In this study, we addressed the regional characteristics of primary production by examining the main driving factors responsible for the regional variability in the Chukchi Sea based on measurements taken in 2012. In addition, we investigated the recent trends in primary production in the Chukchi Sea based on the results of the three RUSALCA

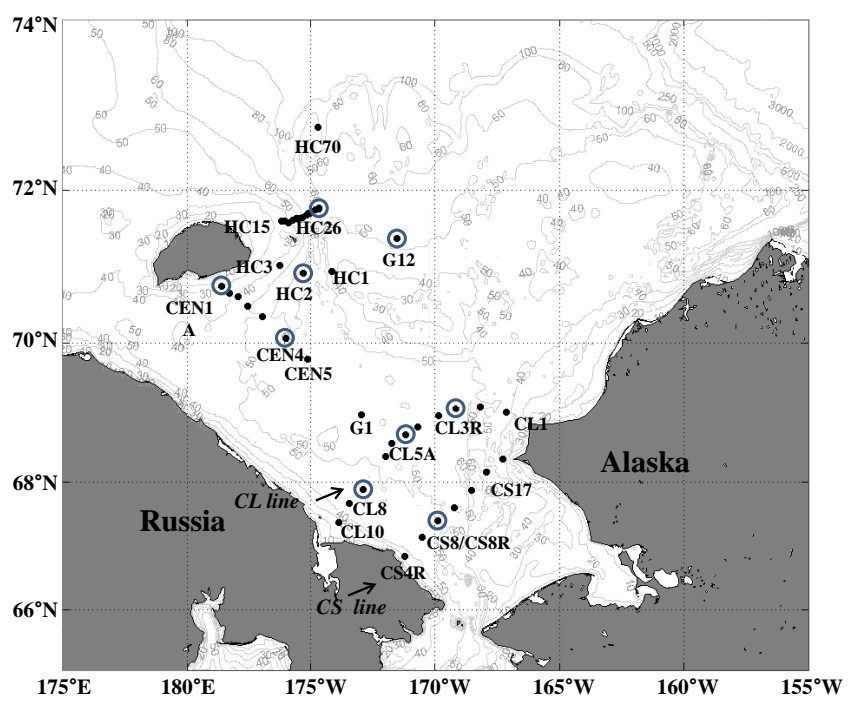

Figure 1. Locations of sampling stations during the 2012 RUSALCA expedition in the Chukchi Sea. The primary production rates were measured at the stations identified by blue circles. CS8R represents a revisit to station CS8.

expeditions (2004, 2009, and 2012) in the Chukchi Sea. Finally, we emphasized the potential effects of freshwater accumulation on the primary production in the Chukchi Sea because changing amounts and distributions of freshwater content could lead to changes in the primary production rates.

\section{Materials and methods}

\subsection{Study area and sampling}

The RUSALCA expedition in 2012 was conducted onboard the Russian vessel Professor Khromov in the Chukchi Sea from 27 August to 16 September. The study area was comprised of several sections between the Bering Strait and the vicinity of Herald Canyon (Fig. 1). To understand the regional characteristics of primary production, the study area was divided into two geographic regions (northern and southern) following Yun et al. (2014). The northern region consisted of stations in the vicinity of Herald Canyon (CEN and HC sections, Fig. 1). The stations in the Chukchi South and Cape Lisburne (CS and CL sections) were included in the southern region. Most of the bathymetric depths in the entire study area were quite shallow, with a mean of $55 \mathrm{~m}$ $(\mathrm{SD}= \pm 11 \mathrm{~m})$. Between the production stations, the depth of euphotic zone from the surface to $1 \%$ light depth varied between 20 and $46 \mathrm{~m}$, with a mean of $29 \pm 10 \mathrm{~m}$ (Table 1 ).

Oceanographic/biological samples were taken from a total of 54 conductivity-temperature-depth (CTD) stations. The vertical profiles of water temperature and salinity were obtained using a Sea-Bird model SBE911plus CTD profiler. Water samples were collected with a stainless-steel rosette 
Table 1. Location, water depth (m), and euphotic depth $\left(Z_{\text {eu }}\right)$ for primary productivity stations in the Chukchi Sea in 2012.

\begin{tabular}{|c|c|c|c|c|c|c|}
\hline \multirow[t]{2}{*}{ Region } & \multirow[t]{2}{*}{ Station } & \multirow{2}{*}{$\begin{array}{l}\text { Date } \\
(\mathrm{mm} / \mathrm{dd} / \mathrm{yy})\end{array}$} & \multicolumn{2}{|c|}{ Location } & \multirow{2}{*}{$\begin{array}{r}\text { Depth } \\
(\mathrm{m})\end{array}$} & \multirow{2}{*}{$\begin{array}{l}Z_{\mathrm{eu}} \\
(\mathrm{m})\end{array}$} \\
\hline & & & Latitude $\left({ }^{\circ} \mathrm{N}\right)$ & Longitude $\left({ }^{\circ} \mathrm{W}\right)$ & & \\
\hline \multirow[t]{5}{*}{ Northern } & CEN4 & $09 / 05 / 12$ & 69.9828 & 175.6857 & 63 & 34 \\
\hline & CEN1A & 09/06/12 & 70.7085 & 178.2988 & 38 & 20 \\
\hline & $\mathrm{HC} 2$ & 09/07/12 & 70.9000 & 175.0127 & 74 & 36 \\
\hline & $\mathrm{HC} 26$ & 09/08/12 & 71.7878 & 174.3945 & 55 & 46 \\
\hline & G12 & $09 / 11 / 12$ & 71.3980 & 171.2597 & 55 & 46 \\
\hline \multirow[t]{6}{*}{ Southern } & CS8 & $08 / 30 / 12$ & 67.4312 & 169.6030 & 51 & 24 \\
\hline & CS17 & 09/01/12 & 68.2983 & 167.0418 & 40 & 22 \\
\hline & CL5A & $09 / 02 / 12$ & 68.6407 & 170.9423 & 59 & 20 \\
\hline & CL3R & $09 / 12 / 12$ & 69.0048 & 168.9000 & 57 & 26 \\
\hline & CL8 & 09/13/12 & 67.8692 & 172.5482 & 53 & 24 \\
\hline & CS8R & $09 / 14 / 12$ & 67.4312 & 169.6030 & 51 & 26 \\
\hline
\end{tabular}

sampler that was equipped with twenty-one $10 \mathrm{~L}$ bottles at every CTD station. The data from the previous RUSALCA expeditions (in 2004 and 2009) were included to understand the recent trends in primary production in the Chukchi Sea.

\subsection{Physical and chemical variables}

The stratification index of the water column $\left(\Delta \sigma_{\mathrm{t}}\right)$ (in $\mathrm{kg} \mathrm{m}^{-3}$ ) was determined as the difference in $\Delta \sigma_{\mathrm{t}}$ values between the surface and the bottom depth according to Yun et al. (2014). The surface mixed layer $\left(Z_{\mathrm{m}}\right)$ was defined as the depth at which the density $(\sigma-t)$ gradient was $0.05 \mathrm{~kg} \mathrm{~m}^{-3}$ higher than the surface density, as in Coupel et al. (2015). The depth of the euphotic zone $\left(Z_{\text {eu }}\right)$ in this study was defined as the depth receiving $1 \%$ of the surface PAR value, as in Lee et al. (2007) and Yun et al. (2014), and was obtained from a Biospherical QSP-2300 PAR sensor (Biospherical Instruments Inc.) that was lowered with the CTD/rosette sampler. The nitracline $\left(Z_{\text {nit }}\right)$ was determined as the depth at which the nitrate gradient was greater than $0.1 \mu \mathrm{M} \mathrm{m}^{-1}$ according to the definition of Coupel et al. (2015).

\subsection{Freshwater content (FWC)}

To assess the surface water freshening, the freshwater content (FWC) was calculated following Carmack et al. (2008):

$\mathrm{FWC}=\int_{z_{\lim }}^{0}\left(1-S(z) / S_{\mathrm{ref}}\right) \mathrm{d} z$

, where $S$ and $S_{\text {ref }}$ are the in situ and reference salinities, respectively, and $Z_{\text {lim }}$ is the depth where $S$ equals $S_{\text {ref }}$ (34.8 on the practical salinity scale). We used a reference salinity of 34.8 following Aagaard and Carmack (1989) for computing freshwater since it has been considered as the mean salinity for the Arctic Ocean.

\subsection{Nutrient concentration measurements}

The discrete water samples used in measuring the nutrient concentrations were obtained from five to nine different depths depending on the water depths. The dissolved inorganic nutrient concentrations (nitrite + nitrate, ammonium, phosphate, and silicate) were analyzed onboard immediately after collection using an automated nutrient analyzer (ALPKEM RFA model 300) following the method of Whitledge et al. (1981).

\subsection{Chlorophyll $a$ concentration measurements}

The water samples used for measuring the chlorophyll $a$ concentration were obtained from four to seven different depths at most stations. The water samples were filtered through Whatman GF/F filters $(24 \mathrm{~mm})$, and the filters were then kept frozen until analysis in the laboratory. The filters were subsequently extracted in a $3: 2$ mixture of $90 \%$ acetone and DMSO in a freezer for $24 \mathrm{~h}$, followed by centrifugation (Shoaf and Lium, 1976). The chlorophyll $a$ concentrations were measured using a Turner Designs model 10-AU fluorometer, which was calibrated using commercially available preparations of purified chlorophyll $a$ (Turner Designs, USA). The methods and calculations used to determine the chlorophyll $a$ concentrations followed the procedure of Parsons et al. (1984).

\subsection{In situ primary production measurements}

The water samples used to measure primary production were collected at six photic depths $(100,50,30,12,5$, and $1 \%$ penetration of the surface irradiance, PAR). At 11 selected morning stations, the in situ primary productions of phytoplankton were measured using a ${ }^{13} \mathrm{C}-{ }^{15} \mathrm{~N}$ dual-tracer technique (Lee and Whitledge, 2005; Lee et al., 2007). This method could be useful for distinguishing the relative im- 
portance of nitrate and ammonium as nitrogen sources for the cell and population (Dugdale and Goering, 1967). We followed the same analytical procedure of Lee et al. (2007) and Yun et al. (2014) to the measure primary production to consistently compare the primary production levels determined in the three studies. Briefly, heavy isotope-enriched (98-99\%) carbon $\left(\mathrm{NaH}^{13} \mathrm{CO}_{3}\right)$, nitrate $\left(\mathrm{K}^{15} \mathrm{NO}_{3}\right)$, and ammonium $\left({ }^{15} \mathrm{NH}_{4} \mathrm{Cl}\right)$ substrates were inoculated in polycarbonate bottles $(1 \mathrm{~L})$ and then incubated on deck in a large polycarbonate incubator cooled with running surface seawater under natural light conditions. After approximately 4 to $5 \mathrm{~h}$ of incubation, all samples were filtered using precombusted $\left(450^{\circ} \mathrm{C}, 4 \mathrm{~h}\right.$ ) glass fiber filters (Whatman GF/F; diameter $=25 \mathrm{~mm}$ ). After $\mathrm{HCl}$ fume treatment, the samples were sent to the Alaska Stable Isotope Laboratory of the University of Alaska, Fairbanks, USA. The abundances of ${ }^{13} \mathrm{C}$ and ${ }^{15} \mathrm{~N}$ and the total amounts of particulate organic carbon (POC) and nitrogen (PON) were determined using a Thermo Finnigan Delta + XL mass spectrometer. Finally, the carbon and nitrogen production rates were calculated based on Hama et al. (1983) and Dugdale and Goering (1967), respectively.

\section{Results}

\subsection{Physical conditions}

The surface temperature ( $\left.T_{\text {sur }}\right)$ varied from -2 to $9{ }^{\circ} \mathrm{C}$ in the study area in 2012 (Fig. 2a). The higher temperatures were found in the eastern side of the southern Chukchi Sea due to the strong influence of the Alaskan Coastal Water (warmer and less saline). The freezing temperatures were observed in the vicinity of the Herald Canyon and gradually decreased toward the northward. At the surface, the salinity varied between 21 and 33 psu. The surface salinity $\left(S_{\text {sur }}\right)$ was considerably lower in the southwestern side compared with the northeastern side of the southern Chukchi Sea (Fig. 2b). The stratification index $\left(\Delta \sigma_{\mathrm{t}}\right)$ in the study area ranged from 0.7 to $9.7 \mathrm{~kg} \mathrm{~m}^{-3}$, with a mean of $3.8 \pm 2.2 \mathrm{~kg} \mathrm{~m}^{-3}$. The stratification in the southern region was higher than in the northern region (Fig. 2c). The general distribution of the stratification index was similar to that of surface salinity because it tended to be high in areas where surface salinity was low. The surface mixed layer $\left(Z_{\mathrm{m}}\right)$ was thinner than $15 \mathrm{~m}$ over the entire study area (Fig. 2d). In the study area, the depths of nitracline $\left(Z_{\text {nit }}\right)$ ranged from 2.5 to $35 \mathrm{~m}$ (Fig. 2e), with a mean nitracline depth of $12.8 \pm 7.7 \mathrm{~m}$.

\subsection{Nutrient distribution}

Since the mean depths of euphotic zone in this study was about $30 \mathrm{~m}$, the distribution of ambient nutrient concentrations integrated from the surface to $30 \mathrm{~m}$ of the water column is shown in Fig. 3. The inventory of nitrite + nitrate ranged from 21.51 to $355.43 \mathrm{mmol} \mathrm{m}^{-2}$, whereas the ammonium inventory ranged from 15.36 to $109.51 \mathrm{mmol} \mathrm{m}^{-2}$
(Fig. 3a and b). High nitrite+nitrate inventories that exceeded $200 \mathrm{mmol} \mathrm{m}^{-2}$ were observed at the center of the CL section (Fig. 3a). The inventories of these nutrients in the southern region $(134.15 \pm 98.41$ for nitrite + nitrate and $61.22 \pm 20.55 \mathrm{mmol} \mathrm{m}^{-2}$ for ammonium, respectively) were approximately 2 times higher than their inventories in the northern region $(75.01 \pm 52.01$ for nitrite + nitrate and $40.49 \pm 20.69 \mathrm{mmol} \mathrm{m}^{-2}$ for ammonium) (see Table 2). The inventory of phosphate in the study area was fairly uniform, with a mean of $24.03 \pm 8.30 \mathrm{mmol} \mathrm{m}^{-2}$ (Fig. 3c). The silicate inventory was generally higher in the southern region than in the northern region (Fig. 3d).

\subsection{Chlorophyll $a$ content}

The distribution of the chlorophyll $a$ content in the upper $30 \mathrm{~m}$ (i.e., mean depth of euphotic zone in this study) of the entire study area is shown in Fig. 4. High chlorophyll $a$ contents of over $80 \mathrm{mg} \mathrm{m}^{-2}$ were observed in the western side of the CL section (from station CL5 to station CL8), and low chlorophyll $a$ contents were shown in the western side of the CS section (Fig. 4). The highest content $\left(286.4 \mathrm{mg} \mathrm{m}^{-2}\right.$ ) was obtained at station CL8. Over the entire study area, the mean chlorophyll $a$ content in the upper $30 \mathrm{~m}$ was $42.7 \mathrm{mg} \mathrm{m}^{-2}\left(\mathrm{SD}= \pm 57.4 \mathrm{mg} \mathrm{m}^{-2}\right)$. The average contents were $21.7\left(\mathrm{SD}= \pm 19.6 \mathrm{mg} \mathrm{m}^{-2}\right)$ and $54.5 \mathrm{mg} \mathrm{m}^{-2}$ $\left(\mathrm{SD}= \pm 67.7 \mathrm{mg} \mathrm{m}^{-2}\right)$ for the northern and southern regions, respectively.

\subsection{Primary production rates}

Overall, the hourly carbon production rates integrated over the euphotic zone from six light depths ranged from 1.1 to $108.6 \mathrm{mg} \mathrm{Cm}^{-2} \mathrm{~h}^{-1}$, with a mean of $27.7 \mathrm{mg} \mathrm{C} \mathrm{m}^{-2} \mathrm{~h}^{-1}$ $\left(\mathrm{SD}=34.7 \mathrm{mg} \mathrm{C} \mathrm{m}^{-2} \mathrm{~h}^{-1}\right)$. The highest primary production rates were found at station CL8 $\left(108.6 \mathrm{mg} \mathrm{C} \mathrm{m}^{-2} \mathrm{~h}^{-1}\right)$ followed by station CL5A ( $82.1 \mathrm{mg} \mathrm{C} \mathrm{m}^{-2} \mathrm{~h}^{-1}$ ) (Fig. 5). In the northern region, the carbon production rates ranged from 1.1 to $18.7 \mathrm{mg} \mathrm{C} \mathrm{m}^{-2} \mathrm{~h}^{-1}$, with a mean of $9.0 \mathrm{mg} \mathrm{C} \mathrm{m}^{-2} \mathrm{~h}^{-1}$ $\left(\mathrm{SD}= \pm 6.4 \mathrm{mg} \mathrm{C} \mathrm{m}^{-2} \mathrm{~h}^{-1}\right)$. In comparison, the average rates in the southern region were approximately 5 times higher than the average rates in the northern region $\left(43.3 \pm 41.7 \mathrm{mg} \mathrm{C} \mathrm{m}^{-2} \mathrm{~h}^{-1}\right)$.

The vertically integrated nitrate production rates ranged from 0.14 to $18.77 \mathrm{mg} \mathrm{NO}_{3} \mathrm{~m}^{-2} \mathrm{~h}^{-1}$, with a mean of $\quad 2.72 \mathrm{mg} \mathrm{N} \mathrm{m}^{-2} \mathrm{~h}^{-1} \quad\left(\mathrm{SD}= \pm 5.51 \mathrm{mg} \mathrm{N} \mathrm{m}^{-2} \mathrm{~h}^{-1}\right)$, whereas the ammonium production rates ranged from 1.16 to $16.16 \mathrm{mgNH}_{4} \mathrm{~m}^{-2} \mathrm{~h}^{-1}$, with a mean of $4.66 \mathrm{mg} \mathrm{NH}_{4} \mathrm{~m}^{-2} \mathrm{~h}^{-1} \quad\left(\mathrm{SD}= \pm 4.38 \mathrm{mg} \mathrm{NH}_{4} \mathrm{~m}^{-2} \mathrm{~h}^{-1}\right.$ (Fig. 6). The total nitrogen (nitrate+ammonium) production rates ranged from 1.31 to $34.94 \mathrm{mg} \mathrm{N} \mathrm{m}^{-2} \mathrm{~h}^{-1}$, with a mean of $7.38 \mathrm{mg} \mathrm{N} \mathrm{m}^{-2} \mathrm{~h}^{-1} \quad\left(\mathrm{SD}= \pm 9.71 \mathrm{mg} \mathrm{N} \mathrm{m}^{-2} \mathrm{~h}^{-1}\right)$. At most stations except for CL8 and CS8R, the ammonium production rates were generally higher than the nitrate production rates (Fig. 6). The average nitrate production rate 

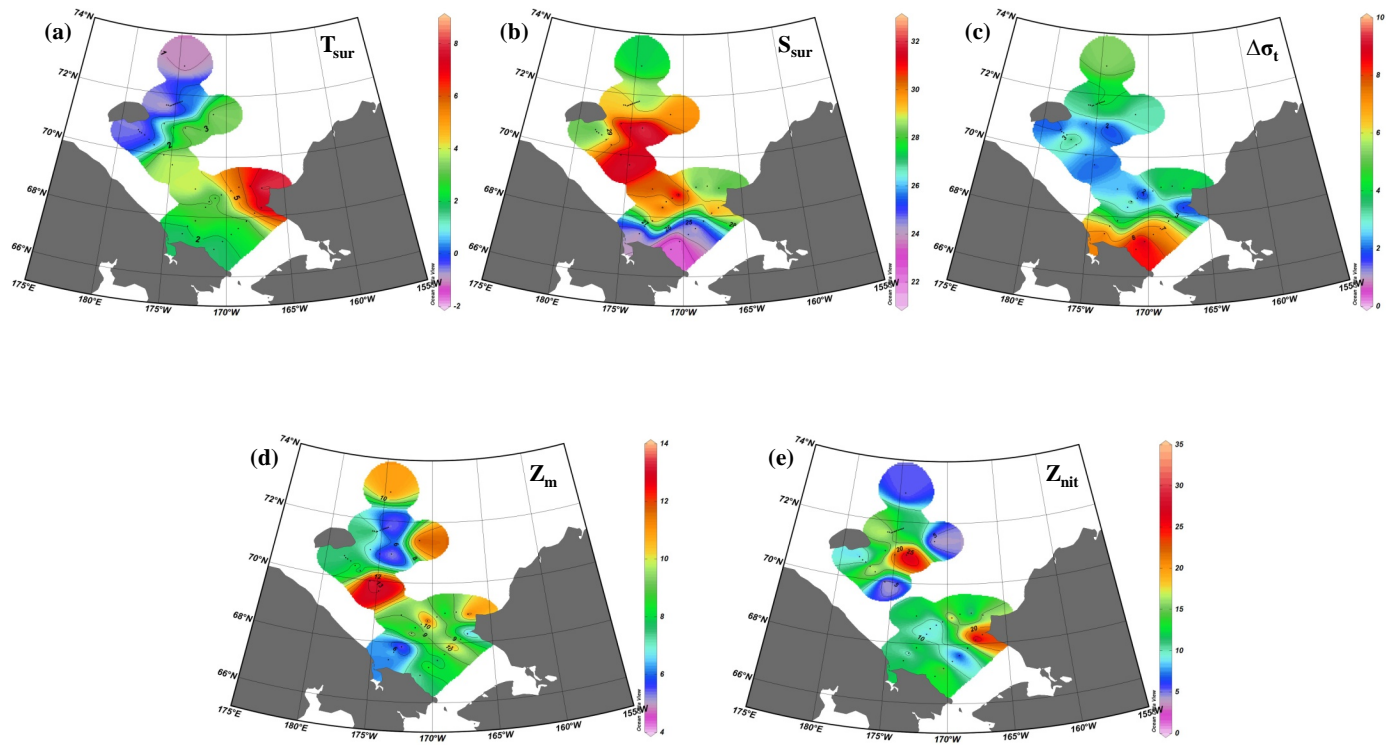

Figure 2. The distribution of surface temperature $\left[T_{\text {sur }}\right]\left({ }^{\circ} \mathrm{C}\right)(\mathbf{a})$, surface salinity $\left[S_{\text {sur }}\right](\mathbf{b})$, stratification index $\left[\Delta \sigma_{\mathrm{t}}\right]\left(\mathrm{kg} \mathrm{m}^{-3}\right)(\mathbf{c})$, surface mixed-layer depth $\left[Z_{\mathrm{m}}\right](\mathrm{m})(\mathbf{d})$, and nitracline depth $\left[Z_{\mathrm{nit}}\right](\mathrm{m})$ (e) during the 2012 RUSALCA expedition.
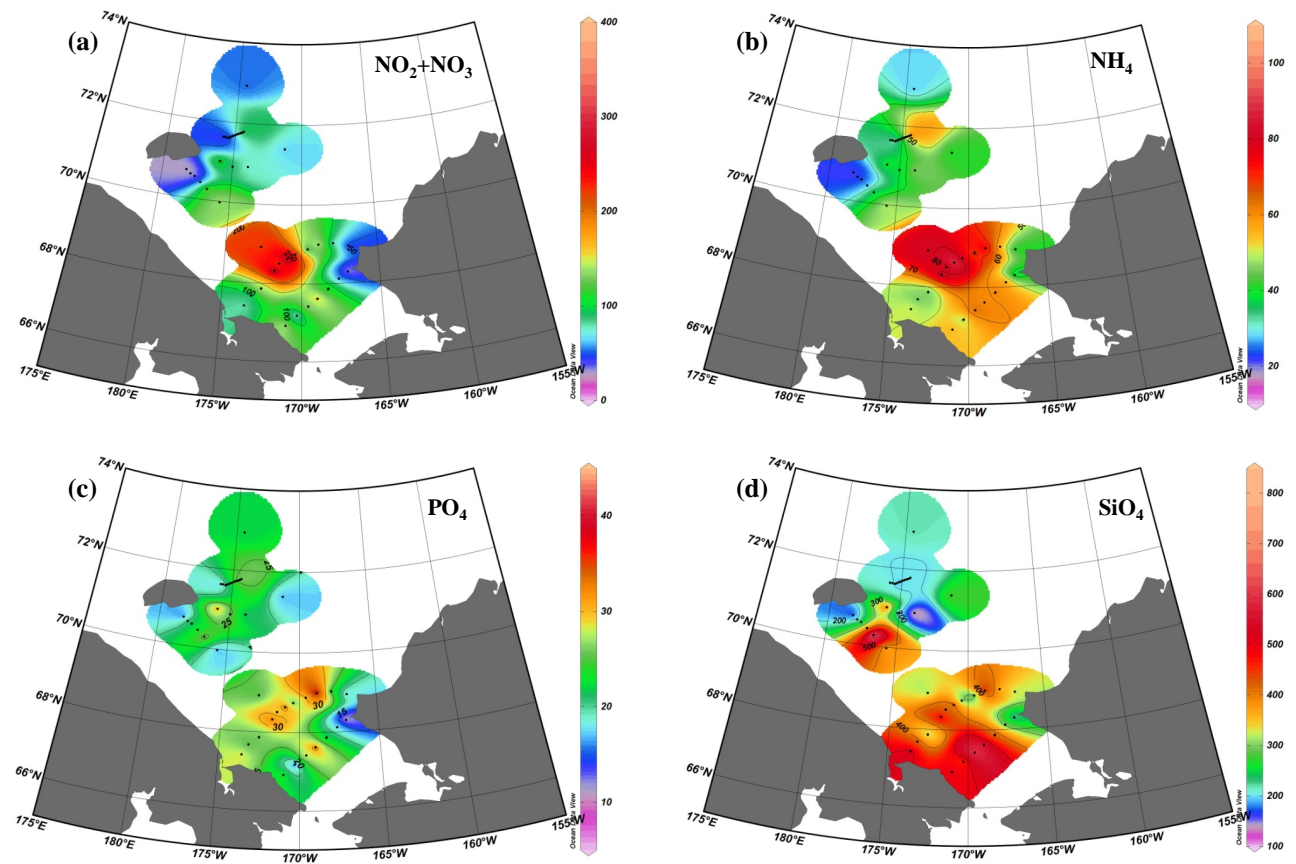

Figure 3. The distributions of the integrated concentrations of ambient nitrite+nitrate $\left[\mathrm{NO}_{2}+\mathrm{NO}_{3}\right]\left(\mathrm{mmol} \mathrm{m}^{-2}\right)(\mathbf{a})$, ammonium $\left[\mathrm{NH} \mathrm{H}_{4}\right]$ $\left(\mathrm{mmol} \mathrm{m}^{-2}\right)(\mathbf{b})$, phosphate $\left[\mathrm{PO}_{4}\right]\left(\mathrm{mmol} \mathrm{m}^{-2}\right)(\mathbf{c})$, and silicate $\left[\mathrm{SiO}_{4}\right]\left(\mathrm{mmol} \mathrm{m}^{-2}\right)$ (d) from the surface to $30 \mathrm{~m}$ during the $2012 \mathrm{RUSALCA}$ expedition.

was $0.41 \mathrm{mg} \mathrm{NO}_{3} \mathrm{~m}^{-2} \mathrm{~h}^{-1}\left(\mathrm{SD}= \pm 0.51 \mathrm{mg} \mathrm{NO}_{3} \mathrm{~m}^{-2} \mathrm{~h}^{-1}\right)$ in the northern region, whereas the average nitrate production rate for the southern region was $4.64 \mathrm{mg} \mathrm{NO}_{3} \mathrm{~m}^{-2} \mathrm{~h}^{-1}$ $\left(\mathrm{SD}= \pm 7.13 \mathrm{mg} \mathrm{NO}_{3} \mathrm{~m}^{-2} \mathrm{~h}^{-1}\right)$. In comparison, the average ammonium production rates for the northern and southern regions were $2.56\left(\mathrm{SD}= \pm 1.74 \mathrm{mg} \mathrm{NH}_{4} \mathrm{~m}^{-2} \mathrm{~h}^{-1}\right)$ and
$6.41 \mathrm{mg} \mathrm{NH}_{4} \mathrm{~m}^{-2} \mathrm{~h}^{-1}$
$\left(\mathrm{SD}= \pm 5.28 \mathrm{mg} \mathrm{NH}_{4} \mathrm{~m}^{-2} \mathrm{~h}^{-1}\right)$ respectively. 
Table 2. Summary of one-way analysis of variance (ANOVA) for environmental variables in two geographic regions of the Chukchi Sea in 2012. The mean values (ranges in parentheses) and their significant differences $(>$ or $<$ ) between the northern and southern regions are given for surface temperature $\left(T_{\text {sur }}\right)$, surface salinity $\left(S_{\text {sur }}\right)$, stratification index $\left(\Delta \sigma_{\mathrm{t}}\right)$, surface mixed-layer depth $\left(Z_{\mathrm{m}}\right)$, nitracline depth $\left(Z_{\text {nit }}\right)$, freshwater content $(\mathrm{FWC})$, nitrite + nitrate inventory of the upper $30 \mathrm{~m}\left(\mathrm{NO}_{2}+\mathrm{NO}_{3}\right)$, ammonium inventory of the upper $30 \mathrm{~m}\left(\mathrm{NH}_{4}\right)$, phosphate inventory of the upper $30 \mathrm{~m}\left(\mathrm{PO}_{4}\right)$, silicate inventory of the upper $30 \mathrm{~m}\left(\mathrm{SiO}_{4}\right)$, and chlorophyll $a$ content in the upper $30 \mathrm{~m}$ $(\mathrm{Chl} a){ }^{*} p<0.05,{ }^{* *} p<0.01,{ }^{* * *} p<0.001$; ns: not significant. $n=52$. Also given are mean and range values for carbon production (CP),

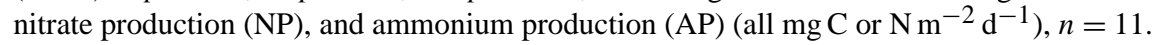

\begin{tabular}{|c|c|c|c|}
\hline Variables & Northern & & Southern \\
\hline$T_{\text {sur }}\left({ }^{\circ} \mathrm{C}\right)$ & $\begin{array}{l}0.62 \\
(-1.33-4.13)\end{array}$ & $<* * *$ & $\begin{array}{l}3.89 \\
(1.60-8.53)\end{array}$ \\
\hline$S_{\text {sur }}$ & $\begin{array}{l}29.27 \\
(27.30-32.04)\end{array}$ & $>*$ & $\begin{array}{l}27.48 \\
(21.48-32.35)\end{array}$ \\
\hline$\Delta \sigma_{\mathrm{t}}\left(\mathrm{kg} \mathrm{m}^{-3}\right)$ & $\begin{array}{l}3.15 \\
(0.79-5.34)\end{array}$ & $<*$ & $\begin{array}{l}4.47 \\
(0.71-9.71)\end{array}$ \\
\hline$Z_{\mathrm{m}}(\mathrm{m})$ & $\begin{array}{l}7.6 \\
(4.0-14.0)\end{array}$ & ns & $\begin{array}{l}8.4 \\
(4.0-14.0)\end{array}$ \\
\hline$Z_{\text {nit }}(\mathrm{m})$ & $\begin{array}{l}13.0 \\
(2.5-30.0)\end{array}$ & ns & $\begin{array}{l}12.6 \\
(2.5-35.0)\end{array}$ \\
\hline $\mathrm{NO}_{2}+\mathrm{NO}_{3}\left(\mathrm{mmol} \mathrm{m}^{-2}\right)$ & $\begin{array}{l}75.01 \\
(21.51-218.22)\end{array}$ & $<*$ & $\begin{array}{l}134.15 \\
(21.82-355.43)\end{array}$ \\
\hline $\mathrm{NH}_{4}\left(\mathrm{mmol} \mathrm{m}^{-2}\right)$ & $\begin{array}{l}40.49 \\
(15.36-86.93)\end{array}$ & $<* *$ & $\begin{array}{l}61.22 \\
(28.54-109.51)\end{array}$ \\
\hline $\mathrm{PO}_{4}\left(\mathrm{mmol} \mathrm{m}^{-2}\right)$ & $\begin{array}{l}22.19 \\
(5.43-34.26)\end{array}$ & ns & $\begin{array}{l}25.95 \\
(8.30-43.57)\end{array}$ \\
\hline $\mathrm{SiO}_{4}\left(\mathrm{mmol} \mathrm{m}^{-2}\right)$ & $\begin{array}{l}245.49 \\
(104.79- \\
800.49)\end{array}$ & $<* * *$ & $\begin{array}{l}410.86 \\
(129.17- \\
669.94)\end{array}$ \\
\hline Chl $a\left(\mathrm{mg} \mathrm{m}^{-2}\right)$ & $\begin{array}{l}21.7 \\
(2.2-69.3)\end{array}$ & $<*$ & $\begin{array}{l}54.5 \\
(3.1-286.4)\end{array}$ \\
\hline $\mathrm{CP}\left(\mathrm{mg} \mathrm{C} \mathrm{m}^{-2} \mathrm{~d}^{-1}\right)$ & $\begin{array}{l}134.7 \\
(16.3-280.7)\end{array}$ & & $\begin{array}{l}649.1 \\
(151.3-1628.9)\end{array}$ \\
\hline $\mathrm{NP}\left(\mathrm{mg} \mathrm{N} \mathrm{m}^{-2} \mathrm{~d}^{-1}\right)$ & $\begin{array}{l}6.1 \\
(2.2-19.9)\end{array}$ & & $\begin{array}{l}69.7 \\
(4.5-281.6)\end{array}$ \\
\hline $\operatorname{AP}\left(\mathrm{mg} \mathrm{N} \mathrm{m}^{-2} \mathrm{~d}^{-1}\right)$ & $\begin{array}{l}38.4 \\
(17.4-83.6)\end{array}$ & & $\begin{array}{l}96.2 \\
(45.0-242.4)\end{array}$ \\
\hline
\end{tabular}

\subsection{Statistical analysis of environmental variables according to geographic regions}

One-way analysis of variance (ANOVA) was performed to assess significant regional differences in the environmental and biological variables of the two geographic regions (i.e., northern and southern). One-way ANOVA revealed significant regional differences for some of the environmental and biological variables in the study area (Table 2). The temperature and salinity of the surface were significantly different due to the effects of various water masses in the region. The stratification also exhibited a significant regional variability due to the higher accumulation of freshwater in the southern region $(p<0.05)$. However, the mean mixedlayer depths were not significantly different, with means of $7.6 \mathrm{~m}(\mathrm{SD}= \pm 2.8 \mathrm{~m})$ and $8.4 \mathrm{~m}(\mathrm{SD}= \pm 2.4 \mathrm{~m})$ for the northern and southern regions, respectively (Table 2). The mean depths of nitracline were similar between the regions, although there were differences between the stations. The ambient nutrient inventory of the upper $30 \mathrm{~m}$ showed highly significant differences, with a higher inventory in the southern region, although the phosphate inventory was not significantly different between the regions (Fig. 3 and Table 2). In addition, the chlorophyll $a$ contents were significantly different $(p<0.05)$, with a value that was approximately 2 times higher in the southern region than in the northern region.

\subsection{FWC distribution}

To understand the potential effects of recent changes in the FWC on the primary production in the Chukchi Sea, the FWC data obtained from the three RUSALCA expeditions were used for a comparison. In 2012, the FWC in the study area were ranged from 2.1 to $8.5 \mathrm{~m}$, with a mean of $4.5 \mathrm{~m}$ $(\mathrm{SD}=1.2 \mathrm{~m})$ (Fig. 7a). The strongest freshwater accumulation was observed in the western side of the CS section and 


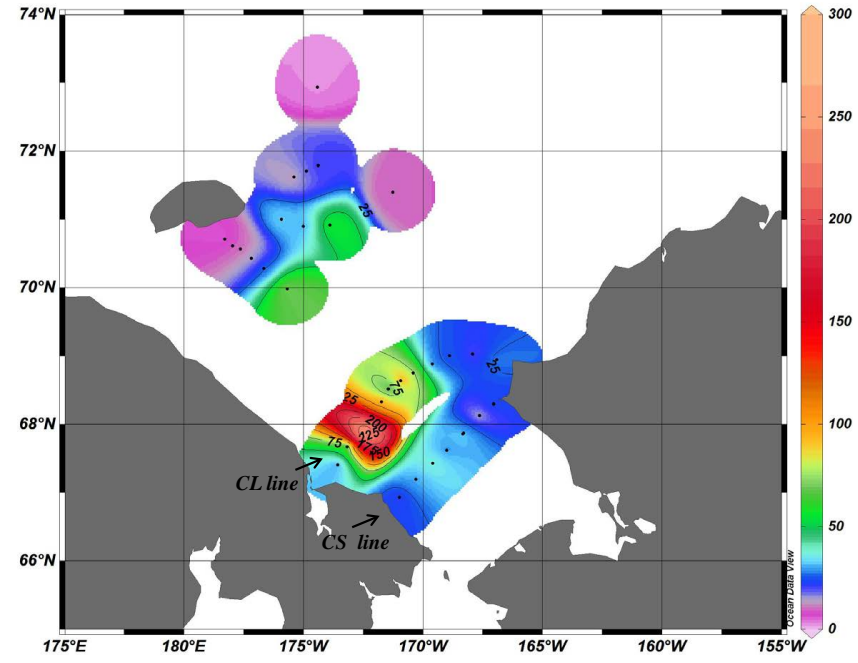

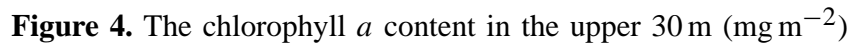
during the 2012 RUSALCA expedition.

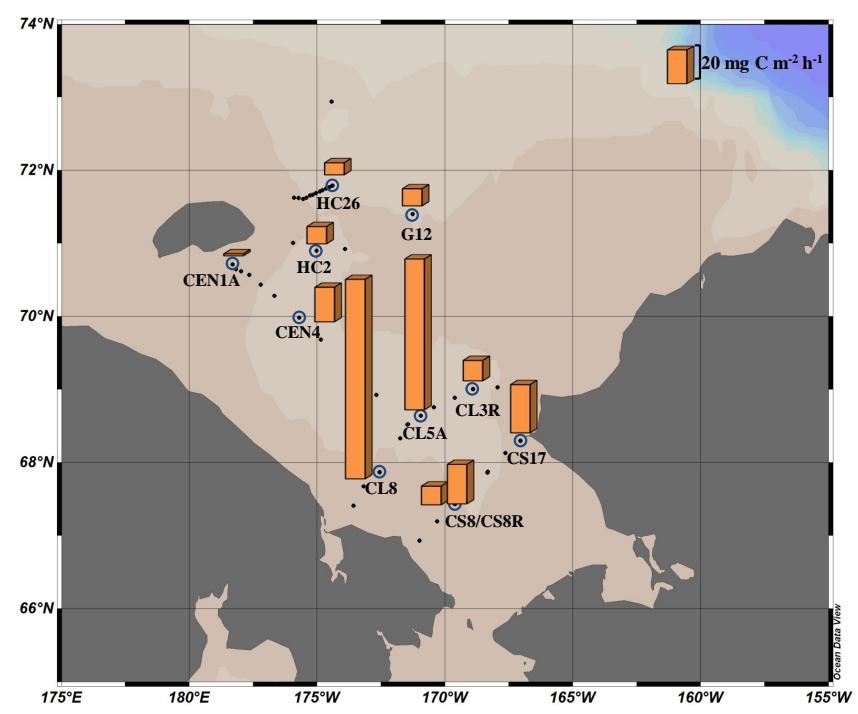

Figure 5. Hourly carbon uptake rates $\left(\mathrm{mg} \mathrm{C} \mathrm{m}^{-2} \mathrm{~h}^{-1}\right)$ integrated from the surface to $1 \%$ light depth during the 2012 RUSALCA expedition.

north of the Herald Canyon (FWC $=6.7-8.5 \mathrm{~m}$ ), whereas the lowest freshwater accumulation was observed at the center of the CL section in the southern region $(\mathrm{FWC}=2.8-3.7 \mathrm{~m})$ (Fig. 7a). The FWC in 2009 ranged from $2.6-11.8 \mathrm{~m}$, with a mean of $5.1 \mathrm{~m}(\mathrm{SD}= \pm 1.7 \mathrm{~m})$ (Fig. $7 \mathrm{~b})$. The mean value in 2009 was a little higher than that of 2012 due to the high accumulation of FWC from the East Siberian Sea and the region north of Herald Canyon (Fig. 7b). In 2009, the FWC in the southern region was evenly distributed with an accumulation of below $6 \mathrm{~m}$. In 2004, the mean FWC was $4.7 \pm 1.3 \mathrm{~m}$ and ranged from 2.0 to $9.9 \mathrm{~m}$ (Fig. 7c). Unlike the observations from 2012 and 2009, the FWC in the southern region

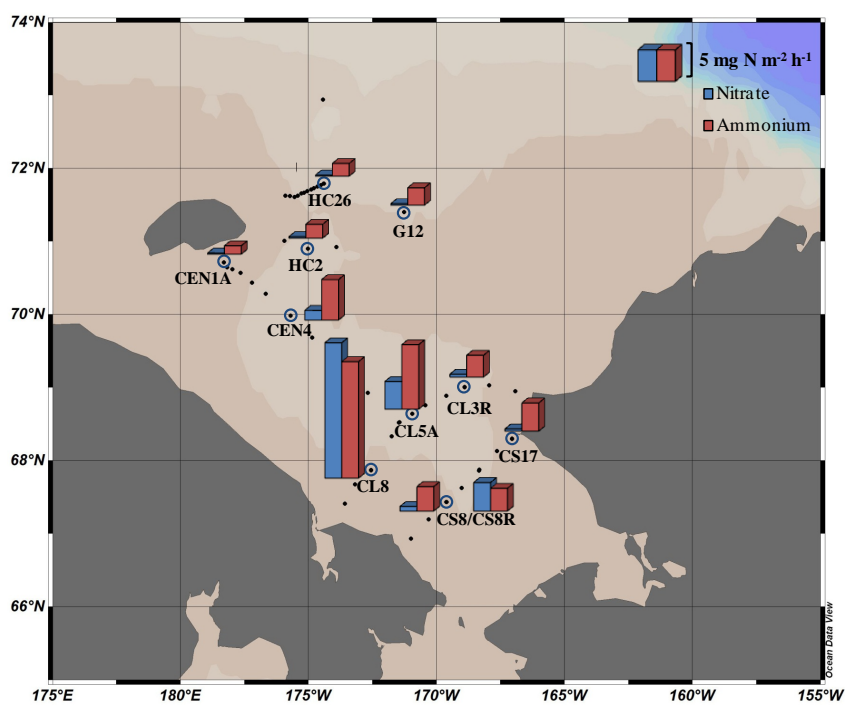

Figure 6. Hourly nitrate and ammonium uptake rates $\left(\mathrm{mg} \mathrm{N} \mathrm{m}^{-2} \mathrm{~h}^{-1}\right)$ integrated from the surface to $1 \%$ light depth during the 2012 RUSALCA expedition.

in 2004 indicated a low accumulation in the western side and a progressive increase in FWC toward the eastern side (Fig. 7c).

\section{Discussion}

\subsection{Regional carbon and nitrogen production rates in 2012}

In this study, there were large differences in the carbon and nitrogen production rates the between southern and northern regions (Figs. 5, 6 and Table 2). The average rate of carbon production in the southern region was about 5 times higher than that of the northern region (Fig. 5 and Table 2). Similarly, the total nitrogen (nitrate+ammonium) production rates were approximately 4 times higher in the southern region than in the northern region (Fig. 6). In particular, the regional differences were much higher for the nitrate production rate than the ammonium production rate (Table 2). We also found that the carbon production rates obtained from all of the RUSALCA expeditions (2004, 2009, and 2012) showed highly significant differences between the regions $(p<0.001, n=43)$ (data not shown).

The regional differences in phytoplankton production rates may have resulted from the different environmental conditions, as revealed the statistical analysis (Table 2). Especially, the different nutrient conditions and thereby different phytoplankton biomasses may be an important reason for the regional differences in the production rates of phytoplankton, since there was a positive relationship between the ambient nutrient inventory (nitrate) and the chlorophyll $a$ content in the upper $30 \mathrm{~m}(r=0.6468, p<0.0001$, 

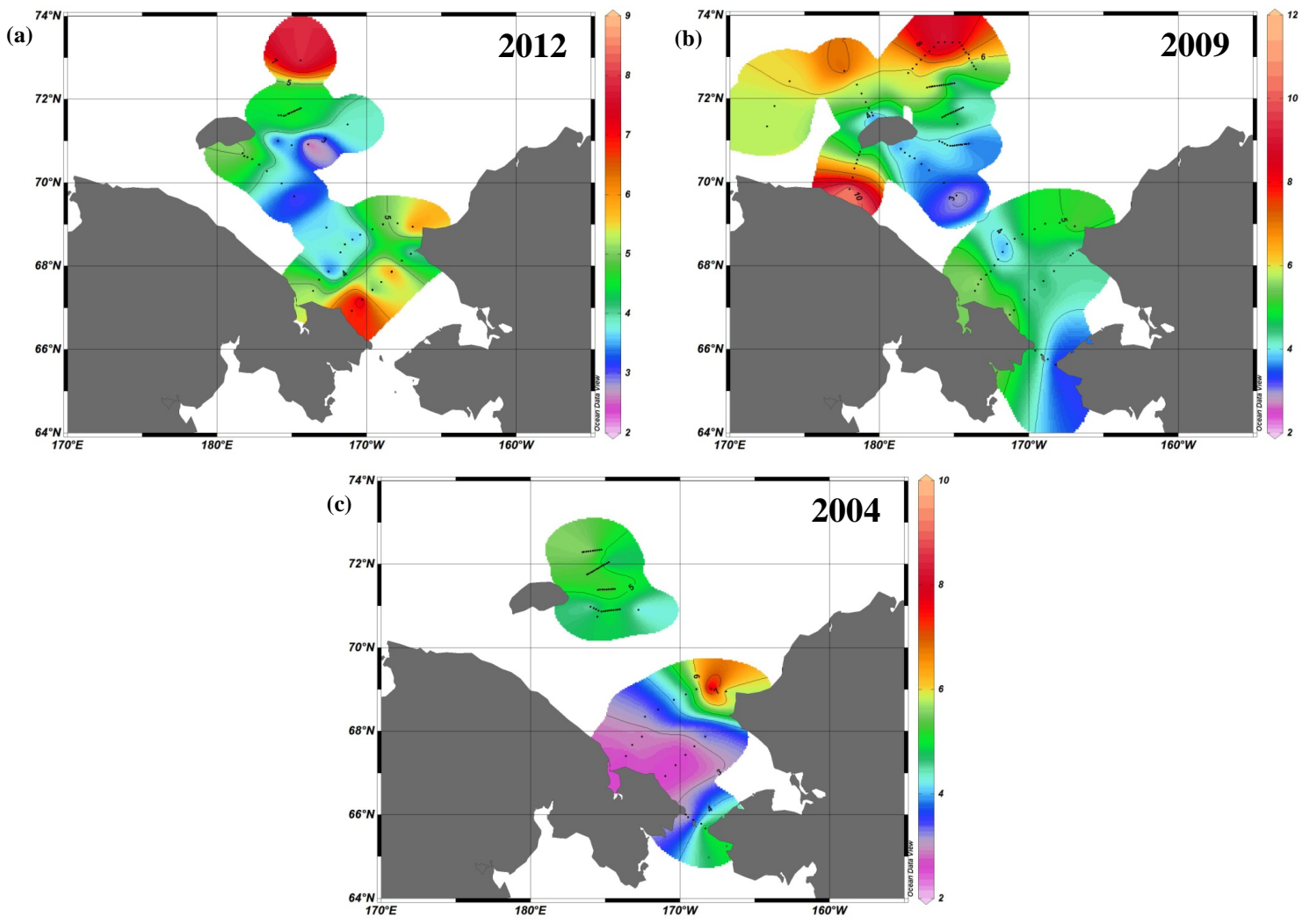

Figure 7. The distributions of Fresh Water Content (FWC in m) in the Chukchi Sea in 2012 (a), 2009 (b), and 2004 (c).

$n=41$ ) (Fig. 8a). Moreover, we found that the carbon, nitrate, and ammonium production rates were significantly correlated with the chlorophyll $a$ content in the upper $30 \mathrm{~m}$ $(r=0.9234, r=0.9641$, and $r=0.9798, p<0.0001, n=11$, respectively) (Fig. 8b). Even though the regional differences in temperature are quite similar to that in primary production rates, there was no significant relationship between temperature and primary production rates in this study. According to Gosselin et al. (1997), the latitudinal variability in the phytoplankton production and biomass were primarily regulated by changes in the surface ice cover and the depths of the surface mixed layer, which determine the amount of light available to the phytoplankton in the water column. However, this was not the case in our study, as the mixed-layer depths were not significantly different between the southern and northern regions of the Chukchi Sea (Table 2).

The production/biomass ratio (P/B ratio), which was calculated by dividing the daily carbon production rate $\left(\mathrm{mg} \mathrm{C} \mathrm{m}^{-2} \mathrm{~d}^{-1}\right)$ by the integrated chlorophyll $a$ concentration $\left(\mathrm{mgChl} \mathrm{a} \mathrm{m}^{-2}\right.$ ), in the southern region $\left(9.61 \pm 4.26 \mathrm{mg} \mathrm{C}(\mathrm{mg} \mathrm{Chl} a)^{-1} \mathrm{~d}^{-1}\right)$ was somewhat higher than the $\mathrm{P} / \mathrm{B}$ ratio in the northern region $(5.46 \pm 1.27 \mathrm{mg} \mathrm{C}$ $\left.(\mathrm{mg} \mathrm{Chl} a)^{-1} \mathrm{~d}^{-1}\right)$. This result indicated better carbon production efficiency by the phytoplankton in the southern region. Therefore, the regional differences in the primary production rates may have been affected by different produc- tion efficiencies in addition to the different phytoplankton biomasses induced under different nutrient conditions.

\subsection{Primary production rate in 2012 compared to the previous RUSALCA expeditions}

Based on a $15 \mathrm{~h}$ photo period in the Chukchi Sea (Hansell and Goering, 1990; Lee et al., 2007; Yun et al., 2014) and the hourly carbon production rates measured in this study, in 2012, the daily carbon production rates integrated from the surface to $1 \%$ light depth ranged from 0.02 to $1.61 \mathrm{~g} \mathrm{C} \mathrm{m}^{-2} \mathrm{~d}^{-1}$. The daily carbon production rate in $2012\left(\right.$ mean $\left.\pm \mathrm{SD}=0.42 \pm 0.52 \mathrm{~g} \mathrm{C} \mathrm{m}^{-2} \mathrm{~d}^{-1}\right)$, which was averaged from the values from all the productivity stations, was quite similar to the daily carbon production rate of $2004\left(\right.$ mean $\left.\pm \mathrm{SD}=0.41 \pm 0.53 \mathrm{~g} \mathrm{C} \mathrm{m}^{-2} \mathrm{~d}^{-1}\right)$ reported by Lee et al. (2007). The production rates (mean $\pm \mathrm{SD}=0.26 \pm 0.24 \mathrm{~g} \mathrm{C} \mathrm{m}^{-2} \mathrm{~d}^{-1}$ ) obtained in 2009 and presented by Yun et al. (2014) were significantly lower than those from 2012 and 2004, which is believed to be due to the different sampling times among the three cruises because the seasonal variation in primary productivity is quite large in this region (Springer and McRoy, 1993; Wang et al., 2005; Hill et al., 2013). These differences in the primary production rates obtained by the three cruises also may have been due to interannual variations in primary productivity in the Chukchi 

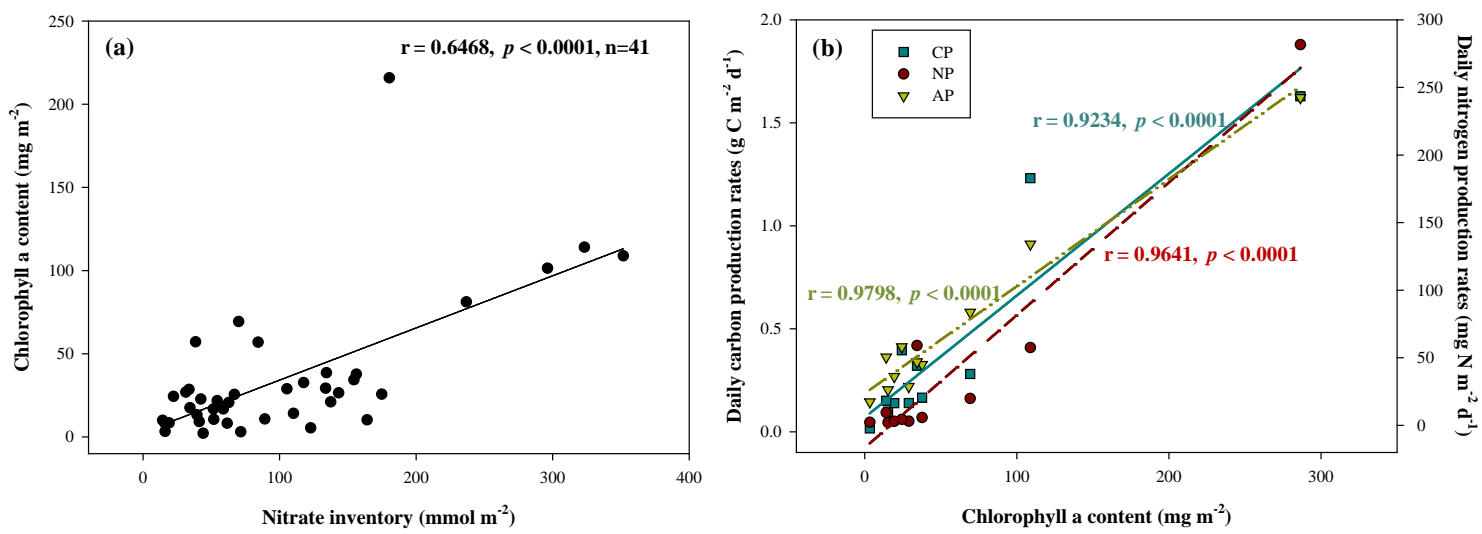

Figure 8. Relationships between (a) nitrate inventory $\left(\mathrm{mmol} \mathrm{m}^{-2}\right)$ and chlorophyll $a$ content $\left(\mathrm{mg} \mathrm{m}^{-2}\right)$ in the upper $30 \mathrm{~m}(n=41)$ and (b) chlorophyll $a$ content $\left(\mathrm{mg} \mathrm{m}^{-2}\right)$ and daily carbon $\left(\mathrm{g} \mathrm{C} \mathrm{m}^{-2} \mathrm{~d}^{-1}\right)$ and nitrogen production rate $\left(\mathrm{mg} \mathrm{N} \mathrm{m}^{-2} \mathrm{~d}^{-1}\right)$ over the euphotic zones $(n=11)$. All data obtained during the 2012 RUSALCA expedition.

Sea, as Hirawake et al. (2012) used satellite remote sensing data obtained from 2002 to 2010 to show that the Chukchi Sea experiences strong interannual variation in August and September.

In 2012, the average daily carbon production rates were $0.66 \mathrm{~g} \mathrm{C} \mathrm{m}^{-2} \mathrm{~d}^{-1}\left(\mathrm{SD}= \pm 0.62 \mathrm{~g} \mathrm{C} \mathrm{m}^{-2} \mathrm{~d}^{-1}\right)$ in the southern region and $0.14 \mathrm{~g} \mathrm{C} \mathrm{m}^{-2} \mathrm{~d}^{-1} \quad\left(\mathrm{SD}= \pm 0.10 \mathrm{~g} \mathrm{C} \mathrm{m}^{-2} \mathrm{~d}^{-1}\right)$ in the northern region. By comparison, the average daily carbon production rates in the southern and northern regions were $0.57\left(\mathrm{SD}= \pm 0.64 \mathrm{~g} \mathrm{C} \mathrm{m}^{-2} \mathrm{~d}^{-1}\right)$ and $0.16 \mathrm{~g} \mathrm{C} \mathrm{m}^{-2} \mathrm{~d}^{-1}$ $\left(\mathrm{SD}= \pm 0.18 \mathrm{~g} \mathrm{C} \mathrm{m}^{-2} \mathrm{~d}^{-1}\right)$ in 2004 , respectively, and 0.38 $\left(\mathrm{SD}= \pm 0.26 \mathrm{~g} \mathrm{C} \mathrm{m}^{-2} \mathrm{~d}^{-1}\right)$ and $0.14 \mathrm{~g} \mathrm{C} \mathrm{m}^{-2} \mathrm{~d}^{-1} \quad(\mathrm{SD}$ $= \pm 0.16 \mathrm{~g} \mathrm{C} \mathrm{m}^{-2} \mathrm{~d}^{-1}$ ) in 2009, respectively. From the regional comparisons, we found that the pattern of primary production in the Chukchi Sea is largely different depending on regions. The primary production rates in the northern region were consistently low, since the regionally low nutrient conditions and phytoplankton biomass. Thus, they were not largely changed among the three cruises. In contrast, the primary production rates for the southern region were considerably variable among the three cruises, although they including seasonal and interannual variations. Since this study revealed that the nutrient is an important factor in controlling primary production, the recent change in primary production for the southern region could be induced by changes in nutrient conditions in the region. The changes in freshwater inputs in the region may have been closely related to the nutrient and primary production variability (detailed in Sect. 4.3).

\subsection{The effects of FWC on the nutrients and primary production in the southern Chukchi Sea}

FWC plays an important role in determining the nutrient distribution/inventory and, therefore, the availability of nutrients for phytoplankton growth in the Arctic Ocean. Coupel et al. (2015) showed that the strong freshening of the Canada
Basin resulted in the deepening of the nitracline, which had a negative impact on primary production. In addition, Yun et al. (2014) reported that the low primary production rate in the Chukchi Sea could be due to the decreases in the nutrient and chlorophyll $a$ concentrations that resulted from the increased input of freshwaters. In 2012, we found that the freshwater had strongly accumulated in the western side of the southern Chukchi Sea and especially in the CS section (Fig. 7a) due to an inflow of fresh Siberian Coastal Water or sea ice meltwater. This could have resulted in the low primary production rates observed in the western region and the CS section of the southern Chukchi Sea (Fig. 5). In contrast, relatively high production rates were observed in the center of the CL section, the region with the lowest accumulation of freshwater (Figs. 5 and 7a). The strong inflow of Siberian Coastal Water from the East Siberian Sea into the Chukchi Sea was also found in 2009, though it was not detected in 2004 (Fig. 7b and c). These inputs of freshwater presumably influenced the nutrient reservoir and its replenishment from deeper layers by altering stratification of the water column (Coupel et al., 2015), eventually driving the observed changes in primary production in the region. Based on data obtained from southern region during three cruises, we found that FWC had a significant negative effect on the nitrate inventory $(r=0.5363$, $p<0.05)$ and primary production rates $(r=0.5645, p<0.05)$ (Fig. 9a and b). As a result, the primary production rates in the Chukchi Sea could be highly significantly correlated with the nitrate inventory $(r=0.7482, p<0.001)$ (Fig. 9c). Therefore, we might conclude that the primary production in the Chukchi Sea could be primarily controlled by nutrient inventory related to FWC variability, as reported in previous studies conducted in different regions of the Arctic Ocean (Tremblay and Gagnon, 2009; Tremblay et al., 2002, 2006; Coupel et al., 2015). However, the influence of ocean circulations should be examined further because the ocean circulation such as Pacific inflow and the Beaufort Gyre can re- 

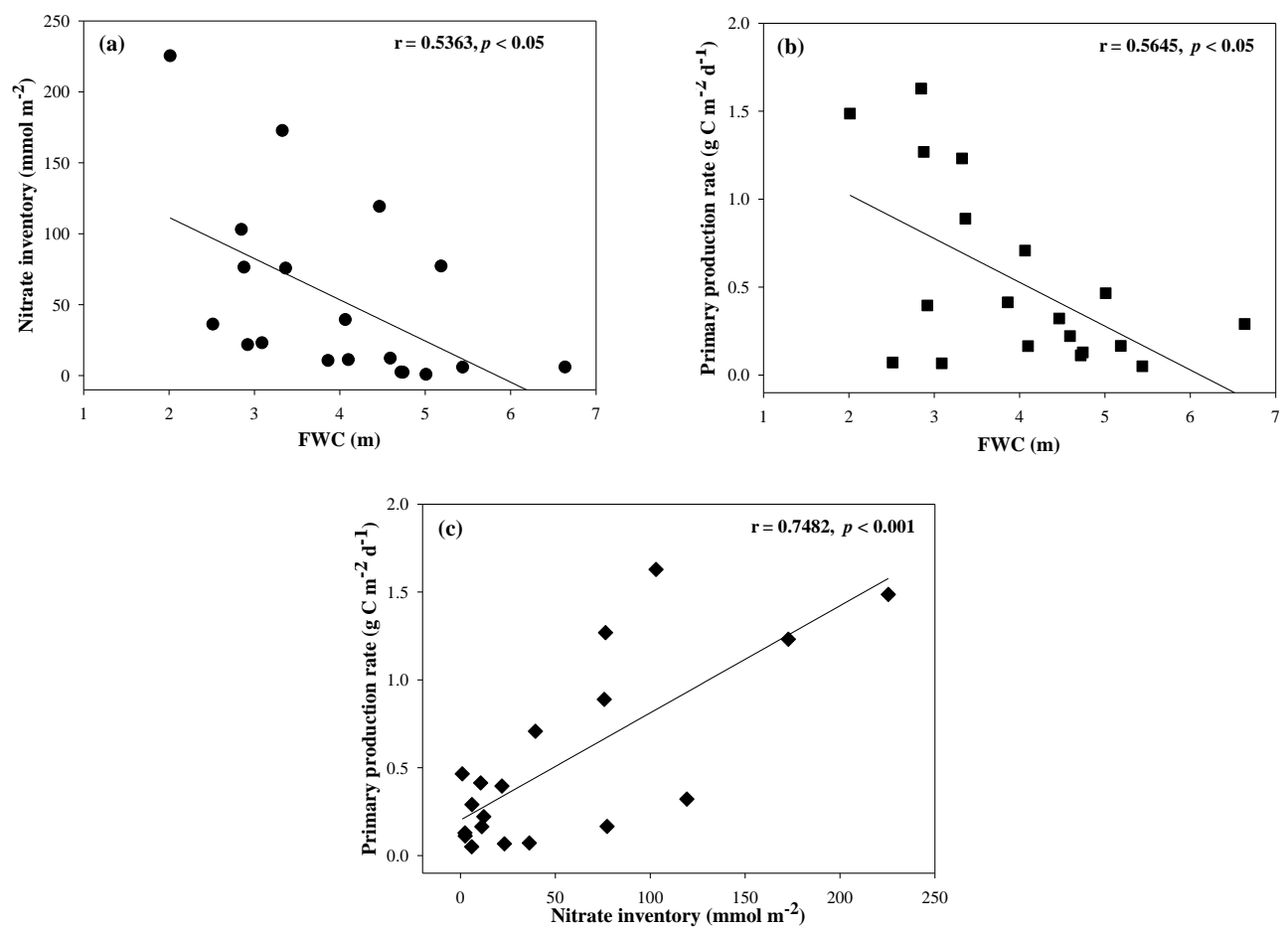

Figure 9. Relationships between (a) FWC $(\mathrm{m})$ and nitrate inventory $\left(\mathrm{mmol} \mathrm{m}^{-2}\right)$, (b) FWC $(\mathrm{m})$ and daily primary production rate (g $\left.\mathrm{C} \mathrm{m}^{-2} \mathrm{~d}^{-1}\right)$, and $(\mathbf{c})$ nitrate inventory $\left(\mathrm{mmol} \mathrm{m}^{-2}\right)$ and daily primary production rate $\left(\mathrm{g} \mathrm{C} \mathrm{m}^{-2} \mathrm{~d}^{-1}\right)$. All data obtained from the southern region during the three RUSALCA cruises.

distribute the amount of freshwater (Giles et al., 2012), eventually leading to regional differences in FWC (Giles et al., 2012; Morison et al., 2012). Additionally, we need to consider the local wind field, as the spatial distribution of FWC is largely dependent on the wind and is controlled by atmospheric pressure patterns (Anderson et al., 2011).

\subsection{Current status of the primary production in the Chukchi Sea}

To understand the recent status of primary production in the Chukchi Sea, the in situ measurements of primary production in the region in recent years were plotted with those from the previous studies in decades ago (Fig. 10). The average carbon production rate from the three RUSALCA cruises in the Chukchi Sea was $0.33 \mathrm{~g} \mathrm{C} \mathrm{m}^{-2} \mathrm{~d}^{-1}$ $\left(\mathrm{SD}=0.40 \mathrm{~g} \mathrm{C} \mathrm{m}^{-2} \mathrm{~d}^{-1}\right)$. In addition, Hill and Cota (2005) reported that the mean daily production rate during the initial ice breakup was $0.8 \mathrm{~g} \mathrm{C} \mathrm{m}^{-2} \mathrm{~d}^{-1}$ in 2002 . The daily production rates obtained by Lee et al. $(2012,2013)$ were 0.54 and $0.86 \mathrm{~g} \mathrm{C} \mathrm{m}^{-2} \mathrm{~d}^{-1}$, respectively (Fig. 10). Even though the different sea ice condition could affect the difference in the productivity, these recent measurements of primary production (Hill and Cota, 2005; Lee et al., 2007, 2012, 2013; Yun et al., 2014; this study) showed significantly lower rates compared with the previously reported rates from the region (Hameedi, 1978; Korsak, 1992; Zeeman, 1992) ( $t$ test,

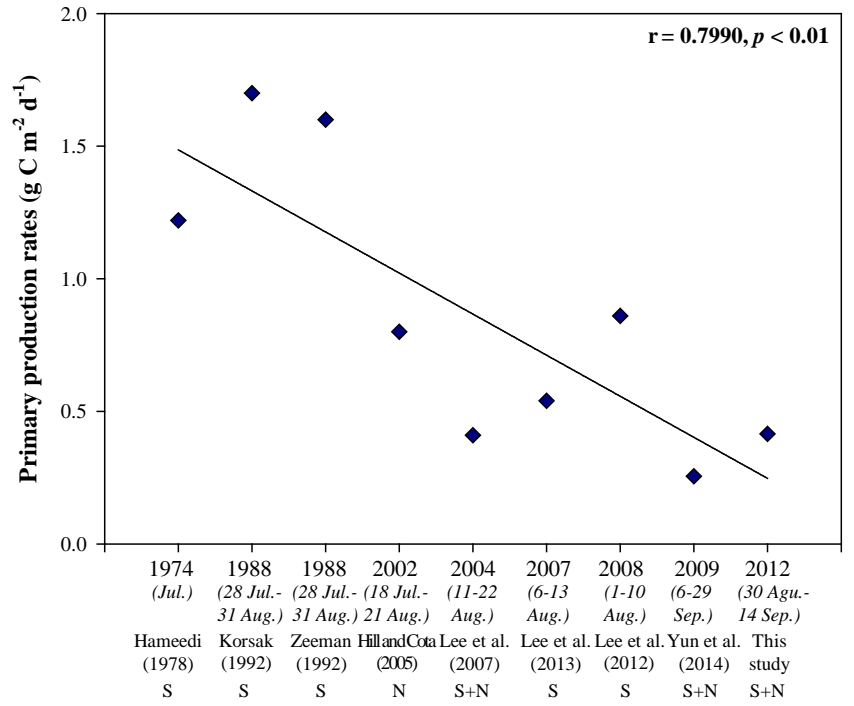

Figure 10. A recent trend of primary production based on in situ carbon uptake measurements $\left({ }^{13} \mathrm{C}\right.$ or $\left.{ }^{14} \mathrm{C}\right)$ in the Chukchi Sea. Study area of each study is indicated by $\mathrm{N}$ or $\mathrm{S}$ for northern and southern Chukchi Sea, respectively.

$p<0.01)$. Moreover, it is obviously shown a decreasing trend of primary production $(r=0.7689, p<0.01)$ (Fig. 10). This is very interesting because primary production could be ex- 
pected to increase in the region due to the increased light availability to the phytoplankton. For example, based on satellite ocean color data, Arrigo et al. (2008) found large increases in the annual net primary production on the continental shelves of the Chukchi Sea as well as Siberian and Laptev seas due to increased open water areas and longer growing seasons. However, the in situ measurements of primary production in recent years (Hill and Cota, 2005; Lee et al., 2007, 2012, 2013; Yun et al., 2014; this study) have shown consistently lower primary production rates compared to those in previous studies.

The strong seasonal and interannual variation in the region could be suggested as a reason for the low primary production, as discussed above. Hill et al. (2013) found that the seasonal variations in primary production in the southern Chukchi Sea peaked in July and then progressively declined in August and September. In fact, the lowest primary production rates given by Yun et al. (2014) were obtained from the late summer season (i.e., from 1 to 30 September 2009) compared with the rates found in the present study (from 30 August to 14 September 2012) or in Lee et al. (2007) (from 11 to 22 August 2004). In comparison, previous studies (Hameedi, 1978; Korsak, 1992; Zeeman, 1992) included the measurements obtained from July to August (Fig. 10). However, their measurements just starting from the end of July were mostly done during August (Korsak, 1992; Zeeman, 1992). Although recent measurements from the three RUSALCA cruises (2004, 2009 and 2012) may not have reflected the highest values (i.e., July) of primary production, the measurements from Hill and Cota (2005) or Lee et al. $(2012,2013)$ include the values in the mid-July and early August. Therefore, the recent low rates of primary production might be reflected by a decreasing trend rather than results of seasonal and interannual variations.

More plausible reason for the recent low primary production in the Chukchi Sea could be due to the decreased concentrations of nutrients and chlorophyll $a$. According to Whitledge and Lee (unpublished data), in recent years, there have been significant decreases of $30-50 \%$ in nutrient concentrations and approximately $40 \%$ in the integrated chlorophyll $a$ concentration in the Bering Strait and the Chukchi Sea. Based on the significant relationships between primary production and the nutrient and FWC (discussed in Sect. 4.3), the recent decrease in nutrient and chlorophyll $a$ concentrations may have been closely related to the changes in freshwater inputs in the region. According to Serreze et al. (2006), there was recently larger import of freshwater through the Bering Strait compared with previous estimates. Therefore, the recent decreases in the concentrations of major inorganic nutrients and chlorophyll $a$ may have resulted in lower primary production rates in the Chukchi Sea.

Recently, the freshwater content in the Arctic Ocean, which includes river discharge, Pacific water inflow through the Bering Strait, sea ice melt water, and net precipitation (Jones et al., 2008), has increased over the past few decades.
If the increased freshwater contents in the Chukchi Sea are continuously observed, the Chukchi Sea might have become a less productive region compared with previous decades.

\section{Conclusions}

This study reported the regional characteristics of primary production in the Chukchi Sea and recent trend of primary production based on in situ measurements. The different nutrient conditions and phytoplankton biomass could be an important reason for the regional differences in the production rates of phytoplankton. Based on comparison between previous studies in decades ago and recent measurements, we found that recent primary production in the Chukchi Sea showed a decreasing trend. The changes in freshwater inputs in the region may have been closely related to the nutrient and primary production variability. Although Coupel et al. (2015) reported that the recent freshening of the Arctic Ocean does not significantly affect primary production in the Chukchi shelf based on comparison with measurements in the deep Canada Basin, our results showed that the freshwater variability in the Chukchi Sea has had a large influence on the recent changes in primary production by controlling the nutrient inventory. If the increased freshwater inflow persists, the primary production in the region will considerably decrease, ultimately resulting in changes in the regional characteristics of primary production. However, large interannual variability in primary production remains despite the statistical significance observed in this study. Therefore, more measurements under various environmental conditions are needed to better understand the recent variations in the primary production in the Chukchi Sea. In particular, there could be some changes in the phytoplankton community structures because the smaller cells benefit more than the larger cells under increased freshening conditions ( $\mathrm{Li}$ et al., 2009).

Acknowledgements. We thank the captain and crew of the Professor Khromov for their outstanding assistance during the cruise. We gratefully acknowledge the physical oceanographers from Woods Hole Oceanographic Institute (M. Swartz, S. Mills, and J. Pietro), who provided the CTD data. We also appreciate NOAA for supporting the RUSALCA program. This study was financially supported by the "2015 Post-Doc. Development Program" of Pusan National University, South Korea. This work was also supported by grants from the Korea-Polar Ocean in Rapid Transition (K-PORT; PM14040) program funded by the Ministry of Oceans and Fisheries, South Korea.

Edited by: M. Yamamoto-Kawai 


\section{References}

Aagaard, K. and Carmack, E. C.: The role of sea ice and other fresh water in the Arctic circulation, J. Geophys. Res., 94, 1448514498, 1989.

Anderson, L. G. Björk, G., Jutterström, S., Pipko, I., Shakhova, N., Semiletov, I., and Wählström, I.: East Siberian Sea, an Arctic region of very high biogeochemical activity, Biogeosciences, 8 , 1745-1754, doi:10.5194/bg-8-1745-2011, 2011.

Ardyna, M., Babin, M., Gosselin, M., Devred, E., Rainville, L., and Tremblay, J.-É.: Recent Arctic Ocean sea ice loss triggers novel fall phytoplankton blooms, Geophys. Res. Lett., 41, 6207-6212, 2014.

Arrigo, K. R., van Dijken, G., and Pabi, S.: Impact of a shrinking Arctic ice cover on marine primary production, Geophys. Res. Lett., 35, L19603, doi:10.1029/2008GL035028, 2008.

Carmack, E., McLaughlin, F., Yamamoto-Kawai, M., Itoh, M., Shimada, K., Krishfield, R., and Proshutinsky, A.: Freshwater storage in the Northern Ocean and the special role of the Beaufort Gyre, in: Arctic-Subarctic Ocean Fluxes: Defining the Role of the Northern Seas in Climate, edited by: Dickson, R. R., Meincke, J., and Rhines, P., Springer, New York, 145-169, 2008.

Comiso, J. C., Parkinson, C. L., Gersten, R., and Stock, L.: Accelerated decline in the Arctic sea ice cover, Geophys. Res. Lett, 35, L01703, doi:10.1029/2007GL031972, 2008.

Coupel, P., Ruiz-Pino, D., Sicre, M. A., Chen, J. F., Lee, S. H., Schiffrine, N., Li, H. L., and Gascard, J. C.: The impact of freshening on phytoplankton production in the Pacific Arctic Ocean, Prog. Oceanogr., 131, 113-125, 2015.

Crane, K. and Ostrovskiy, A.: Introduction to the special issue: Russian-American Long-term Census of the Arctic (RUSALCA), Oceanography, 28, 18, doi:10.5670/oceanog.2015.54, 2015.

Dugdale, R. C. and Goering, J. J.: Uptake of new and regenerated forms of nitrogen in primary productivity, Limnol. Oceanogr., 12, 196-206, 1967.

Giles, K. A., Laxon, S. W., Ridout, A. L., Wingham, D. J., and Bacon, S.: Western Arctic Ocean freshwater storage increased by wind-driven spin-up of the Beaufort Gyre, Nat. Geosci., 5, 194197, 2012.

Gosselin, M., Levasseur, M., Wheeler, P. A., Horner, R. A., and Booth, B. C.: New measurements of phytoplankton and ice algal production in the Arctic Ocean, Deep-Sea Res. Pt. II, 44, 16231644, 1997.

Hama, T., Miyazaki, T., Ogawa, Y., Iwakuma, T., Takahashi, M., Otsuki, A., and Ichimura, S.: Measurement of photosynthetic production of a marine phytoplankton population using a stable ${ }^{13} \mathrm{C}$ Isotope, Mar. Biolo., 73, 31-36, 1983.

Hameedi, M. J.: Aspects of water column primary productivity in the Chukchi Sea during summer, Mar. Biol., 45, 37-46, 1978.

Hansell, D. A. and Goering, J. J.: Pelagic nitrogen flux in the northern Bering Sea, Cont. Shelf Res., 10, 501-519, 1990.

Hill, V. and Cota, G. F.: Spatial patterns of primary production on the shelf, slope and basin of the western Arctic in 2002, DeepSea Res. Pt. II, 52, 3344-3354, 2005.

Hill, V. J., Matrai, P. A., Olson, E., Suttles, S., Steele, M., Codispoti, L. A., and Zimmerman, R. C.: Synthesis of integrated primary production in the Arctic Ocean: II. In situ and remotely sensed estimates, Prog. Oceanogr., 110, 107-125, 2013.
Hirawake, T., Shinmyo, K., Fujiwara, A., and Saitoh, S.: Satellite remote sensing of primary productivity in the Bering and Chukchi Seas using an absorption-based approach, ICES J. Mar.Sci., 69, 1194-1204, 2012.

Jones, E. P., Anderson, L. G., Jutterstrom, S., Mintrop, L., and Swift, J. H.: Pacific freshwater, river water and sea ice meltwater across Arctic Ocean basins: results from the 2005 Beringia Expedition, J. Geophys. Res., 113, C08012, doi:10.1029/2007JC004124, 2008.

Korsak, M. N.: Primary production of organic matter, in: Results of the Third Joint US-USSR Bering and Chukchi Seas Expedition (BERPAC): Summer 1988, edited by: Nagel, PA, US Fish and Wildlife Service, Washington, DC, 215-218, 1992.

Kwok, R., Cunningham, G. F., Wensnahan, M., Rigor, I., Zwally, H. J., and Yi, D.: Thinning and volume loss of Arctic sea ice: 2003-2008, J. Geophys. Res., 114, C07005, doi:10.1029/2009JC005312, 2009.

Lee, S. H. and Whitledge, T. E.: Primary and new production in the deep Canada Basin during summer 2002, Polar Biol., 28, 190197, 2005.

Lee, S. H., Whitledge, T. E., and Kang, S. H.: Recent carbon and nitrogen uptake rates of phytoplankton in Bering Strait and the Chukchi Sea, Cont. Shelf Res., 27, 2231-2249, 2007.

Lee, S. H., Joo, H. M., Liu, Z., Chen, J., and He, J.: Phytoplankton productivity in newly opened waters of the western Arctic Ocean, Deep-Sea Res. Pt. II, 81-84, 18-27, 2012.

Lee, S. H., Yun, M. S., Kim, B. K., Saitoh, S., Kang, C.-K., Kang, S. H., and Whitledge, T. E.: Latitudinal carbon productivity in the Bering and Chukchi Seas during the summer in 2007, Cont. Shelf Res., 59, 28-36, 2013.

Li, W. K. W., McLaughlin, F. A., Lovejoy, C., and Carmack, E. C.: Smallest algae thrive as the Arctic Ocean freshens, Science, 326, 539, doi:10.1126/science.1179798, 2009.

McLaughlin, F. A. and Carmack, E. C.: Deepening of the nutricline and chlorophyll maximum in the Canada Basin interior, 2003-2009, Geophys. Res. Lett., 37, L24602, doi:10.1029/2010GL045459, 2010.

McPhee, M. G., Proshutinsky, A., Morison, J. H., Steele, M., and Alkire, M. B.: Rapid change in freshwater content of the Arctic Ocean, Geophys. Res. Lett., 36, L10602, doi:10.1029/2009GL037525, 2009.

Morison, J., Kwok, R., Peralta-Ferriz, C., Alkire, M., Rigor, I., Andersen, R., and Steele, M.: Changing Arctic Ocean freshwater pathways, Nature, 481, 66-70, 2012.

Overland, J. E. and Wang, M.: When will the summer Arctic be nearly sea ice free?, Geophys. Res. Lett., 40, 2097-2101, 2013.

Parsons, T. R., Maita, Y., and Lalli, C. M.: A manual of chemical and biological methods for seawater analysis, Pergamon Press, New York, 173 pp., 1984.

Rabe, B., Karcher, M., Schauer, U., Toole, J. M., Krishfield, R. A., Pisarev, S., Kauker, F., Gerdes, R., and Kikuchi, T.: An assessment of Arctic Ocean freshwater content changes from the 1990s to the 2006-2008 period, Deep-Sea Res. Pt. I, 58, 173-185, 2011.

Serreze, M. C., Barrett, A. P., Slater, A. G., Woodgate, R. A., Aagaard, K., Lammers, R. B., Steele, M., Moritz, R., Meredith, M., and Lee, C. M.: The large-scale freshwater cycle of the Arctic, J. Geophys. Res., 111, C11010, doi:10.1029/2005JC003424, 2006. 
Shoaf, W. T. and Lium, B. W.: Improved extraction of chlorophyll-a and -b from algae using dimethyl sulfoxide, Limnol. Oceanogr., 21, 926-928, 1976.

Springer, A. M. and McRoy, C. P.: The paradox of pelagic food webs in the northern Bering Sea - III. Patterns of primary production, Cont. Shelf Res., 13, 575-599, 1993.

Stroeve, J., Serreze, M., Drobot, S., Gearheard, S., Holland, M., Maslanik, J., Meier, W., and Scambos, T.: Arctic sea ice extent plummets in 2007, EOS Trans., AGU, 89, 13-14, 2008.

Stroeve, J. C., Markus, T., Boisvert, L., Miller, J., and Barrett, A.: Changes in Arctic melt season and implications for sea ice loss, Geophys. Res. Lett., 41, 1216-1225, 2014.

Tremblay, J.-E. and Gagnon, J.: The effect of irradiance and nutrient supply on the productivity of Arctic waters: a perspective on climate change, in: Influence of Climate Change on the Changing Arctic and Sub-Arctic Conditions, edited by: Nihpul, J. C. J. and Kostianoy, A. G., Springer Science, Business Media B.V., 2009.

Tremblay, J.-E., Gratton, Y., Fauchot, J., and Price, N. M.: Climatic and oceanic forcing of new, net, and diatom production in the North Water, Deep-Sea Res. Pt. II, 49, 4927-4946, 2002.

Tremblay, J.-E., Michel, C., Hobson, K. A., Gosselin, M., and Price, N. M.: Bloom dynamics in early opening waters of the Arctic Ocean, Limnol. Oceanogr., 51, 900-912, 2006.

Wang, J., Cota, G. F., and Comiso, J. C.: Phytoplankton in the Beaufort and Chukchi Seas: Distribution, dynamics, and environmental forcing, Deep-Sea Res. Pt. II, 52, 3355-3368, 2005.

Whitledge, T. E., Malloy, S. C., Patton, C. J., and Wirick, C. D.: Automated nutrient analysis in seawater, Brookhaven National Laboratory Technical Report BNL 51398, 1981.

Woodgate, R. A., Aagaard, K., and Weingartner, T. J.: A year in the physical oceanography of the Chukchi Sea: Moored measurements from autumn 1990-1991, Deep-Sea Res. Pt. II, 52, 3116-3149, 2005a.
Woodgate, R. A., Aagaard, K., and Weingartner, T. J.: Monthly temperature, salinity, and transport variability of the Bering Strait throughflow, Geophys. Res. Lett., 32, L04601, doi:10.1029/2004GL021880, 2005b.

Woodgate, R. A., Aagaard, K., and Weingartner, T. J.: Interannual changes in the Bering Strait fluxes of volume heat and freshwater between 1991 and 2004, Geophys. Res. Lett., 33, L15609, doi:10.1029/2006GL026931, 2006.

Woodgate, R. A., Weingartner, T. J., and Lindsay, R.: Observed increases in Bering Strait oceanic fluxes from the Pacific to the Arctic from 2001 to 2011 and their impacts on the Arctic Ocean water column, Geophys. Res. Lett., 39, L24603, doi:10.1029/2012GL054092, 2012.

Yamamoto-Kawai, M., McLaughlin, F. A., Carmack, E. C., Nishino, S., Shimada, K., and Kurita, N.: Surface freshening of the Canada Basin, 2003-2007: River runoff versus sea ice meltwater, J. Geophys. Res., 114, C00A05, doi:10.1029/2008JC005000, 2009.

Yun, M. S., Whitledge, T. E., Gong, M., and Lee, S. H.: Low primary production in the Chukchi Sea shelf, 2009, Cont. Shelf Res., 76, 1-11, 2014.

Zeeman, S. I.: The importance of primary production and $\mathrm{CO}_{2}$, in: Results of the Third Joint US-USSR Bering and Chukchi Seas Expedition (BERPAC): Summer 1988, edited by: Nagel, P. A., US Fish and Wildlife Service, Washington, DC, 39-49, 1992. 